\title{
General Introduction of the Shura Council in Saudi Arabia and Parliamentary Diplomacy
}

\author{
Shaker Ahmed Alshareef \\ Correspondence: Shaker Ahmed Alshareef, United Kingdom. \\ Received: November 24, 2020 \\ Accepted: March 17, $2021 \quad$ Online Published: April 8, 2021 \\ doi:10.11114/ijlpa.v4i1.5208 \\ URL: https://doi.org/10.11114/ijlpa.v4i1.5208
}

\begin{abstract}
Aim: The thesis aims to evaluate the role of the Shura Council in Saudi Arabia's transition and identify if Shura Council can be a catalyst for change in the nation's foreign policy. Saudi's economy is over-relying on oil production, which increases the Kingdom's vulnerability due to uncertainties in the oil markets and other risks. Saudi's vision 2030 aims to decrease Saudi Arabia's dependence on oil and expand the Kingdom's economic resources. The vision 2030 is anchored on three pillars: solidifying the Kingdom's locus in the heart of the Arab and Islamic nations; the quest to become an international investment powerhouse; the Kingdom's strategic site with the capacity to be a hub that connects three continents Africa, Asia, and Europe.
\end{abstract}

Method: The thesis adopts literature review as the main method to establish the composition and effectiveness of the Shura council its design functions.

Findings: As currently constituted, the Shura council cannot freely champion effective foreign policies and regulations that support the Kingdom's goals. Shura council is fully under the kings' absolute power, denying them the opportunity to meet their democratic mandate.

Concision: The Shura studies and interpret the laws, development plans, and the annual reports of Ministries and Government Sectors. Hence, the council also proposes and amend laws. As long as the Shura Council Members are still King's appointees, the political, social, and economic reforms that Saudi Arabians are eagerly waiting for will take decades to come by. Human rights violations are still evident.

Recommendations: The study recommends constitutional monarchy adoption, need for human rights, and fundamental freedom laws to be upheld and allow public participation in legislative process. Strengthening the parliament's oversight roles require the Kingdom to grand Shura Council's independence granting power to partake a vote of no confidence, hearing, interpellation and make committees of inquiry where need be to help Saudi to attain vision 2030 goals.

Keywords: Shura Council (Majlis Ash-Shura), Sharia, Sura, Absolute Monarchy, Foreign policy, Parliament, King, Quran, Vision 2030

\section{Introduction}

Diplomacy to this context defines a political phenomenon of influencing the behavior, and decisions of foreign government including people through negotiation and other measured short of war of violence. Relevant to this thesis, official, public, parliamentary are the main forms of diplomacy. Official Diplomacy, according to De Magalhaes in 1988, is a tool of foreign policy used towards the founding and development of agreements between governments of different nations through the application of mediators mutually recognized by the two parties. Parliamentary diplomacy defines a means which two or more parliaments conduct an ongoing dialogues with respect to key international issues. Public diplomacy on the other hand denotes any government-sponsored efforts geared towards communication directly with the foreign publics to set a dialogue aimed at informing an influencing the foreign public to adopt an idea. Generally, the principles of diplomacy entails the four key elements; an active political system enabling the choice and replacement of governments via a free, fair and credible elections: active people's participation, protection of human rights and the rule of law. The kingdom of Saudi Arabian' diplomacy and democracy is under heavy criticism, due to authoritarian rules that the governance system portrays. Authoritarian rule is believed to be as a result of absolute monarchy in the kingdom. Therefore, the thesis focus on parliamentary democracy as a means of embracing and supporting democracy in the kingdom. A qualitative method is adopted in the thesis. Qualitative approach provided depth and details and creates openness encouraging the study to expand on the responses. The study depends on 
secondary data collected online from reputable search engines like Google scholar. However, the general outline of the thesis are as provided later in chapter one.

\section{Background of the Study}

The Kingdom of Saudi Arabia, also referred by many as the "land of the two holy mosques," has traveled a rocky road form the time she earned her independence on September 23, 1932, to the present times. Many know Saudi as land that oozes precious natural resources like oil. The resources have been the epitome of significant controversies as well as a blessing to the country. ${ }^{1}$ Even though many nations in the African and European continent seek cordial relationships with Saudi, the relationship with the US has been a rocky experience due to terrorism accusations. ${ }^{2}$ In all these controversies and bumpy relations, the Kingdom is keen on pursuing a political, economic, and legal transition as part of the vision 2030.

Saudi Arabia is heavily dependent on oil. In the event of a turbulent oil market, the country is at risk of suffering a financial crisis. The year 2016 marked the beginning of the long road towards vision 2030. The vision aim at decreasing Saudi Arabia's dependence on oil and expand the Kingdom's economic resources. ${ }^{3}$ The vision 2030 is anchored on three pillars: solidifying the Kingdom's locus in the heart of the Arab and Islamic nations; the quest to become an international investment powerhouse; the Kingdom's strategic site to be a hub that connects three continents Africa, Asia, and Europe. Saudi Arabia reiterated that the Kingdom, as of 2030, should have developed a vibrant society, a flourishing economy, and an ambitious nation. ${ }^{4}$ Hence, ensuring that every citizen realizes his short and long term dreams.

In the quest of a vibrant society, the Kingdom recognizes the significance of a society where every member enjoys a happy and fulfilling life as a solid benchmark for economic prosperity. ${ }^{5}$ The Kingdom's vibrant society was established under solid roots and foundations that embrace modern Islam, Saudi's heritage, national pride, and Islamic culture. A vibrant society should equally offer world-class entertainment options, care in the community, and efficient social and health care. ${ }^{6}$ Anything less would mark unfulfilled promises to the people who may, in turn, withdraw their support for the country that has worked hard to build and pledged loyalty to both within and across the borders.

Under economic themes, the vision 2030 seeks to establish an environment that unlocks business opportunities, creates jobs for all Saudis to relieve economic burdens on the country. ${ }^{7}$ The Kingdom aims to achieve economic themes by leveraging Saudi Arabia's unique locations and its potential to attract the best talents and boost global investment. ${ }^{8}$ Global investment requires legal redress by setting international laws that support Saudi in its quest to be an economic hub for the region while expanding its international economic quests. The Kingdom recognizes that Saudi has rewarding opportunities to its younger generation, which is considered the most important asset to the kingdom. Thus, Saudi aims to build a rewarding culture that is marked by determination and nurture skills and opportunities to realize an individual's potential.

The Kingdom of Saudi also realized that investing in the future is vital for economic development as part of the vision. Thus, diversifying of Saudi's economy is important for suitability. The Kingdom's long-term plan is to increase its

1 Aljarallah, Sulaiman, and Russell Lock. "An exploratory study of software sustainability dimensions and characteristics: end user perspectives in the Kingdom of Saudi Arabia (KSA)." In Proceedings of the 12th ACM/IEEE International Symposium on Empirical Software Engineering and Measurement (pp. 2, 2018.)

2 AlGhonaim, AL-ATTAR, Santiago, Zakaria, and Kamal. "SUN-201 Characteristics Of Dialysis And Renal Transplantation In The Kingdom Of Saudi Arabia." Kidney International Reports (5, no. 3, 2020) 283.

${ }^{3}$ Ibid 283.

${ }^{4}$ Moshashai, Daniel, Andrew Leber, and James Savage. "Saudi Arabia plans for its economic future: Vision 2030, the National Transformation Plan and Saudi fiscal reform." British Journal of Middle Eastern Studies (47, no. 3, 2020) 381.

5 AlGhonaim, AL-ATTAR, Santiago, Zakaria, and Kamal. "SUN-201 Characteristics of Dialysis and Renal Transplantation in the Kingdom Of Saudi Arabia." Kidney International Reports (5, no. 3, 2020) 283.

6 Aljarallah, Sulaiman, and Russell Lock. "An exploratory study of software sustainability dimensions and characteristics: end user perspectives in the Kingdom of Saudi Arabia (KSA)." In Proceedings of the 12th ACM/IEEE International Symposium on Empirical Software Engineering and Measurement (pp. 2, 2018.)

7 Moshashai, Daniel, Andrew Leber, and James Savage. "Saudi Arabia plans for its economic future: Vision 2030, the National Transformation Plan and Saudi fiscal reform." British Journal of Middle Eastern Studies (47, no. 3, 2020) 381

8 AlGhonaim, AL-ATTAR, Santiago, Zakaria, and Kamal. "SUN-201 Characteristics of Dialysis and Renal Transplantation in the Kingdom Of Saudi Arabia." Kidney International Reports (5, no. 3, 2020) 283. 
ranking among the 20 world's largest economies. Notwithstanding the dwindling and economic slowdowns experienced around the globe, the country is investing significantly in promising new growth sectors to promote diversity in the economy and privatize government services. ${ }^{9}$ Currently, the country sits at a crossroads of significant international trade routes between Africa, Europe, and Asia. However, with the forward gear in the economic growth and investment ambitions, the country seeks to maximize its benefits in the exceptional geographic positions to influence trade in these regions.

As an ambitious nation, Saudi Arabia seeks to create a high performing government that is accountable, transparent, and effective in its service delivery to Saudis. The country has the ambition to empower its nationals, the nonprofit, and profit sectors to realize their social, economic, and political objectives. Even though Saudi is a hereditary government structured, the King aims to ensure that the government's roles and requirements and meets the needs of the people. The government seeks to maintain highest levels of transparency and accountability towards the financial managements and creating agile public organizations and effectively develop systems that can easily be tracked. Achieving the vision 2030 goals would mean increasing the household savings from $6 \%$ to $10 \%$ of the total household income.

According to McKinsey Global Institute (2015), Saudi's vision 2030 is viewed by many experts as a strong level in moving the country from the high oil prices of the past decade towards laying the groundwork for genuine transformation of the economy. ${ }^{10}$ The entire reliance on oil and natural gas, with their prices fluctuating beyond any capability to forecast, has long kept the economy exposed to uncertainties. ${ }^{11}$ Saudi Arabia seeks to promote its membership in the G20. The Kingdom has been a participant of the G20 Summit since 2008 during the Washington meeting at the time the world experienced one of the worst financial crises. As a member of the G20 Summit, the Kingdom has taken several measures in the sector of momentary policy, trade, and financial sectors, which has helped reduce the effects of the global financial crisis and enhance the performance of the Saudi's economy.

In this context, the role of the Consultative Council, Shura Council, is questioned. What is the exact role of the parliamentary system in Saudi Arabia with respect to the formulation of legislation? What parliamentary diplomacy's role in the promotion of foreign policy? Is it meant to advance the participatory approach to legislation? If so, will it advance the cause of foreign policy, particularly that the country is eager to become a hub connecting three continents? If not, what are the political, cultural, historical, social, and economic forces making constitutionalism and constitutionalizing normative trends in guiding the legal and political reform of the state? What is the Islamic perspective in this constitutionalism? To maintain the legitimacy of the governance structures and functions, what democratic reforms can be sought to strengthen the consultative and participatory approaches to governing?

The common roles of parliament such as representation, oversight, and legislation vary in their effectiveness from one state to another. This depends on several factors. The most notable among them, based on the solid case studies conducted recently in Africa, include "type of political and voting system, formal legislative powers, political will, political space, and technical ability."12 Despite the absence of a consensus on the determinants of good governance, there is growing empirical evidence linking good governance with better economic and social outcomes. ${ }^{13}$ The potentially strong oversight role of the Shura Council is recommended for good governance. However, it is worthwhile to examine how constitutionalism and representative governance are deeply rooted in the Islamic practice of ruling. Some argued that "these precepts have traditionally been narrowly defined, and historically hardly ever applied after the first four khalifas (i.e., rulers), they have never been openly challenged or denied by either the ruling regimes or the traditional schools." ${ }^{14}$ Contrary to this conservative stance towards Shura and its practice, there is a reformist construction with an agenda to expand the scope of the consultative processes within communities to be in line with the modern democratic systems. In this context, the leadership role comes as extremely important for an initial public debate about the reformist agenda. In Saudi the King is often the head of both state and government. The consultative

9 Aljarallah, Sulaiman, and Russell Lock. "An exploratory study of software sustainability dimensions and characteristics: end user perspectives in the Kingdom of Saudi Arabia (KSA)." In Proceedings of the 12th ACM/IEEE International Symposium on Empirical Software Engineering and Measurement (pp. 2, 2018.)

${ }^{10}$ McKinsey Global Institute. "Saudi Arabia beyond Oil: The Investment and Productivity Transformation." (2015).

11 Aljarallah, Sulaiman, and Russell Lock. "An exploratory study of software sustainability dimensions and characteristics: end user perspectives in the Kingdom of Saudi Arabia (KSA)." In Proceedings of the 12th ACM/IEEE International Symposium on Empirical Software Engineering and Measurement (pp. 2, 2018.)

12 Johnson, John K. The Role of Parliament in Government. The World Bank Institute. Washington, USA. (2005)

${ }^{13}$ Straub, Stephane. "Empirical Determinants of Good Institutions: Do We Know Anything?" (2000).

${ }^{14}$ Sulaimanal, Sadek Jawad. The Shura Principle in Islam. Al-Hewar Center website. (1999) 
${ }^{15}$ Assembly, Majlis ash-Shura or Shura Council has a mandate to effectively advise the king through legislative means to act on social, economic, political, religious, and any matters including international diplomacy issues.

\section{The Contemporary General Theory of Shura Council and Parliamentary Diplomacy? And why is it Important to People and Nations?}

The historical background of Shura (Consultation) dates back to the days of the late King Abdul-Aziz. As of 1924, the king called for Shura's application in the lives of the people and governance. ${ }^{16}$ Thus, the King made Shura a foundation of his government towards fulfilling the divine order. The king resorted to the application of Sharia as per the Qur'an and the arthritic Sunnah, described as the teachings and deeds of the Prophet Mohammed, peace be granted unto him. Of significance in the lives of the Saudis could be to look into the journey of Shura in the Kingdom. Shura is, therefore, the foundation upon which Prophet Mohammed encouraged all Muslims to lead their lives' affairs in liaison with individuals who are to be influenced by such decisions. Thus, to some extent, Shura acts as a counselor.

The first elected national council was established in 1924 and named The Consultative National Council. The council was under the chairmanship of one Sheik Abdul Gadir Al-Shebi. The council had twelve participants with the function of drafting basic laws for the country's administration. At the initial stages, no law exited to point out the roles of the council. Nonetheless, the council worked for six months. ${ }^{17}$ However, in 1925, the previous council was disbanded, allowing twelve councilors to represent the twelve districts of Mecca. The election rule was that among the elected members, two religious leaders and a member in charge of commerce were to be found. Sultan further nominated three additional members from distinguished citizens of Mecca. As of 1925, Sheik Mohammed Al-Marzooqi was the head of the council with Sheik Abdul Gadir Al-Shebi as the vice and Mohammed Suroor Al-Sabban as the Secretary to the council. In the same year, the instruction for council formation was in form of six articles with the qualifications of individuals. ${ }^{18}$ Voting dates and eligibility of voters, regulating affairs of the court, commerce, municipalities, endowment, security, and education were among the council's key jurisdictions, as presented in the article. The council was also mandated to provide solutions to the social tradition that did not contradict Shariah's provisions.

In 1926, King Abdul-Aziz issued approval for the enaction of new Basic Laws of Governance. It is contained in the new jurisdiction where the sections of councils and Majlis Ash-Shura are listed in items 28, 29, 31, 36, and 37. The term limit was one year for the elected council members. ${ }^{19}$ Upon the dissolution of the previous council, a royal decree permitted the amendment of the fourth section of the Basic Laws of Governance that deals with the Majlis Ash-Shura. The 1927 council had eight members who served two for years, of which the government elects four members in consultation with the eminent experts while the government appoints the other four. ${ }^{20}$ The members appointed must have two of the members of residents of Najid regions. The council was to meet twice a week but would make more meetings upon request of the president.

The 1928 council was directed through 14 articles upon which the new laws were written. The council members were once more 12, with the articles insisting that the vice president is to be elected by the king while the other vice president is an appointee of the council. ${ }^{21}$ Within the same year, the council developed an appendix consisting of seven articles for its laws. The new article proposed to promote the council's works. Hence, the articles were developed and presented as internal bylaws but Majlis Ash-Shura. The council went on to exercise its authority under the new laws without any amendment until 1953, in which a council of ministers was established. The government decided to distribute many jurisdictions of the Majlis Ash-Shura between the government apparatus and the Council of Ministers. Even under reduced power, Majlis Ash-Shura continued to discharge its constitutional mandate to the people and the government. Records present that between the reign of the late King Abdul-Aziz and the late King Khalid's reign, 6222 sessions were

15 Aljarallah, Sulaiman, and Russell Lock. "An exploratory study of software sustainability dimensions and characteristics: end user perspectives in the Kingdom of Saudi Arabia (KSA)." In Proceedings of the 12th ACM/IEEE International Symposium on Empirical Software Engineering and Measurement (pp. 2, 2018.)

${ }^{16}$ Cordesman, Anthony H. Saudi Arabia: Guarding the desert kingdom. Routledge, 2019

17 ibid

18 Shafiq, Muhammad. "The role and place of shura in the Islamic polity." Islamic Studies 23, no. 4 (1984): 419-441.

${ }_{19}$ Cordesman, Anthony H. Saudi Arabia: Guarding the desert kingdom. Routledge, 2019

${ }^{20}$ Al-Raysuni, Ahmad. Al-Shura: The Qur'anic principle of consultation. International Institute of Islamic Thought (IIIT), 2013.

21 AlGhonaim, AL-ATTAR, Santiago, Zakaria, and Kamal. "SUN-201 Characteristics Of Dialysis And Renal Transplantation In The Kingdom Of Saudi Arabia." Kidney International Reports (5, no. 3, 2020) 283. 
held by the old council. The old council also issued 9349 conclusions under 51 council terms.

In the current Majlis Ash-Shura, several changes had been made to facilitate the economic, religious, and social reforms in Saudi. Earlier, the late King Fahd bin Abdul-Aziz facilitated the modernization of the major laws of Saudi. The king delivered the historical speck in 27th Sha'ban 1412 H (March 1, 1992) and introduced the Majlis Ash-Shura laws, provincial Council Laws, and the Basic Law of Governance. ${ }^{22}$ In chapter one, the first article declares the Kingdom as a Sovereign Arab Islamic State. The religion under the constitution was Islam supported by the Qur'an. The Sunna (Traditions) of the Prophet (PBUH) was also be in application. The first article further stamps Arabic as the language of the Kingdom. In the second article, the citizens must pledge allegiance (bay'a) to the king who must be amongst the sons of the founder of the Kingdom, King Abdulrahman Al-Faisal Al-Saud, and the progenies of the king. ${ }^{23}$ In chapter six, the authority of the state includes judicial, executive, and regulatory authority. Hence, the king acts as the ultimate arbiter of all authorities.

King Fahd Bin Abdulaziz Al-Saud on Sunday 27th Shaban 1414H declared the laws of the province with the main aim of improving the standards if administrative work as well as development in the provinces as stated in the first article. The law of the provinces also aimed to maintain both security and order and further guarantees the citizens their rights and freedom in compliance with the Sharia. ${ }^{24}$ The provinces' laws provide that both the Kingdom and the government seat within the provinces are formed as per the provisions of the Royal Decree with the advice of the interior minister, Emir. Emir or very province must maintain security, implement the court's rulings upon unveiling their final dispositions, and guarantees human rights and freedom.

The law of the Consultative Council as part of the Royal Decree provides that a member of the Majlis Ash-Shura must not be younger than 30 years, should be a Saudi National by both decent and birth, and the individual must be a competent person who recognizes good character. Article three provides that the Majlis Ash-Shura has a chairperson and six individuals who are appointees of the king and must equally be scholars and men of knowledge, specialization, and expertise. ${ }^{25}$ The rights and duties of the members are on the Royal Decree. A member who fails to take up his duties or neglects his work is tried as per the Royal Decree and the rules of the land as outlined in chapter 6 laws of Majlis Ash-Shura. Additionally, it is against the provision of the Laws of the Majlis Ash-Shura for a member to exploit his membership for self-interest. ${ }^{26}$ Therefore, every member must live to the expectation of the Kings, citizens, the Holy book as the constitution, and the entire Royal provisions. In democracies such as the UK, the Member of Parliament can equality become government minister with key responsibilities and still meet the needs of its constituents. However, Article 9 of the Laws of Majlis Ash-Shura provides that no member should combine his legislative roles with another government post. The members are equally denied assuming any leadership of a company unless authorized by the King.

Article 13 provides Majlis Ash-Shura members have a fixed term of four years from the day of Royal Decree to form a new council. The provisions of the laws declare that the next council must be formed at least two months before the termination of an existing council. However, the current council must remain effective until the formation of a new council. ${ }^{27}$ The newly-selected members should not be less than $50 \%$ of the entire council members. Either the chairman or the deputy must equally be present to officiate the meeting. Just like in the UK, the treaties are made by the president upon the advice of the two-thirds of the senators, the international treaties, laws, and concessions are issued and amended by the Royal Decrees upon the study by the Majlis Ash-Shura. ${ }^{28}$ The laws in article 23 further grant the ten-members of Majlis Ash-Shura the power to propose new drafts of law or an amendment of a law already in practice and submit to the chair of the Council. The chairperson, therefore, is answerable to the king.

On November 24, 2000, upon the formation of nee Majlis Ash-Shura, King Fahd replaced the 1928 laws and supported

${ }^{22}$ Cordesman, Anthony H. Saudi Arabia: Guarding the desert kingdom. Routledge, 2019

23 ibid

${ }^{24}$ ibid

${ }^{25}$ Cordesman, Anthony H. Saudi Arabia: Guarding the desert kingdom. Routledge, 2019

${ }^{26}$ Al-Raysuni, Ahmad. Al-Shura: The Qur'anic principle of consultation. International Institute of Islamic Thought (IIIT), 2013.

27 AlGhonaim, AL-ATTAR, Santiago, Zakaria, and Kamal. "SUN-201 Characteristics Of Dialysis And Renal Transplantation In The Kingdom Of Saudi Arabia." Kidney International Reports (5, no. 3, 2020) 283.

28 Al-Raysuni, Ahmad. Al-Shura: The Qur'anic principle of consultation. International Institute of Islamic Thought (IIIT), 2013. 
the bylaws that were established on August 22 1993. Hence, the first term council, which operated between 1993 and 1997, had 60 members. ${ }^{29}$ However, the membership was increased to 90 in the council that operated between 1997 and 2001. The next term, which was between 2001 and 2005, had 120 members with the 2005 and 2009 council having 150 members. Upon the council's expansion between 1997 and 2001, Majlis Ash-Shura secured a place in the International Parliamentary Union towards the end of 2003.

From its inception, Majlis Ash-Shura has been a male-dominated affair, and no one even the past kings envisioned the membership by women. Traditionally, the Islamic state ignored the role of women in leadership. According to Jalajel (2016), Islamic laws traditionally prohibited women from being heads of state and being prayer leaders. ${ }^{30}$ However, feminist Islamic women have chosen to challenge these stances even though there is considerable opposition from the broader Muslim community. The fruits of such struggle have seen women assume leadership or membership in public and private sectors in countries like Saudi Arabia.

In January 2013, King Abdullah granted women thirty seats on the council upon the Royal Decree release. The king stated that women must hold at least a fifth of the seats in the council. The decree further provided that the religious veil must restrain a woman appointed to the council, be committed to Islamic Shariah disciplines, and non-engagement in any form of violence. ${ }^{31}$ The women in the council must enter the building through different gates from the male's entrance, and the communication system in the building should allow the women and men to have conversations. The first woman as the deputy chairperson in the human rights and petition committee was Thurayya Obeid. Lubna Al Ansari was selected the deputy chairperson in the health and environmental committee while Zainab Abu Talib chosen the deputy chairperson of the information and cultural committee.

The development and promotion of women's rights in the Kingdom are structured within tight limitations. Traditionally, Jalajel says that women served as a symbol of traditional ideals in the kingdom's religious bodies that historically limited women's citizenship rights in Saudi. ${ }^{32}$ As evident in the appointment of thirty women in the council, the shift is a nationalist plan focusing on economic modifications as in the vision 2030. Vision 2030 seems to be a hybrid form of transformation in Saudi that aims to entrust leadership into women's hands from the current 1.27 to 5\%. ${ }^{33}$ Through the appointment of women, the country seeks to ensure. As earlier stated, the outside world, such as the American continent, and Europe, has criticized the Islamic states as dictators who thwarts gender equality. However, through vision 2030 and women involvement in the council's affair, Saudi Arabia responds to the critics that the Kingdom values women and that their potentials would greatly be natured within and outside the Kingdom. Hence, women's involvement plans and goals in Saudi will be greater economic integration and foreign investments as more women will be allowed to make decisions at national, provincial, and local levels for the betterment of the entire Saudi nation. ${ }^{34}$ Hence, the programs involving women is a process that is equally articulated in the theory of Neopatriarchy. Neopatriarchy structure provides that gender relations in Saudi will continue to be implemented in the current states. The result of the implementation is a hybrid of society where some women ascend to leadership positions while others remains to enforce strict rules, as well as public policies to ensure a stature of conventional, traditional society is maintained.

\section{Functions and Importance}

Shura Council consists of chosen members whose chief task is to study the proposed laws. As opposed to major democracies in the world where the parliament members have legislative roles of making the laws, the Shura Council only study and make a recommendation to the King otherwise called advising of the king ${ }^{35}$ Upon studying the laws, the recommendations are surrendered to the king, who makes decisions on which issues should be called Saudi Council of Ministers. Further regulations in the current Shura Council were amended to allow any member to submit a

29 Cordesman, Anthony H. Saudi Arabia: Guarding the desert kingdom. Routledge, 2019

30 Jalajel, David Solomon. Women and Leadership in Islamic Law (2016).

31 Alem, Sarah M. "When We Tell You We Can Do It, Believe Us: An Analysis of the Legislation and Policies Related to the Employment of Women with Disabilities in the Kingdom of Saudi Arabia." (2020).

32 Jalajel, David Solomon. Women and Leadership in Islamic Law (2016).

${ }^{33}$ Moshashai, Daniel, Andrew Leber, and James Savage. "Saudi Arabia plans for its economic future: Vision 2030, the National Transformation Plan and Saudi fiscal reform." British Journal of Middle Eastern Studies (47, no. 3, 2020) 381

34 AlGhonaim, AL-ATTAR, Santiago, Zakaria, and Kamal. "SUN-201 Characteristics Of Dialysis And Renal Transplantation In The Kingdom Of Saudi Arabia." Kidney International Reports (5, no. 3, 2020) 283.

${ }^{35}$ Almutairi, Abdulhamid H. "Resolving insurance disputes in the Kingdom of Saudi Arabia: a critical assessment of the Insurance Dispute Committee." (2020). 
resolution straight to the king as opposed to previous councils that submission was only permitted to the king by the council's chairperson and bypassing the Council of Ministers. Thus, the Shura Council has been granted more mandate, including the financial verdicts on matters of difference between the two councils. Since any resolution on the council must be passed by not less than two-thirds of the members, obtaining a majority votes in the council on mates such as gender reforms proves to be an uphill task. ${ }^{36}$ Conservative males in the council may pose a challenge to gender issues at the same time women may fail to support matters that diminish their potentials as women. For instance, Nora Bin Adwan, as the chair of women's research division at King Saud University, headed a Shura battle on the suggested gender reform solutions like the law against sexual harassment. Adwan considered the list to be an introduction of a mixed-gender work environment. Following the standoff, some women registered an official complaint against the member for using the term "gender mixing."

On another juncture Bid Adwan requested the removal of endorsements for the government to support the international agreements and treaties regarding women's rights form the Shura deliberations of the Kingdom's $10^{\text {th }}$ developmental plan. The plan was documented at the end of every five years by the Ministry of planning to be ascended to by the king and Shura council. Subsequently, thirty council members submitted a transcribed appeal to decline the elimination of the recommendations, and two women members of the council decided to walk out of the meeting, which was seen as an unprecedented move. Hence, the women protested the speaker's denial to recognize their request to discuss the removal.

As part of the Shura Council's function to the people of Saudi, the empowering of the women into the council has led to the championing of gender equality. The current council must reach an agreement before gender issues are supported by the council as opposed to the traditional Shura council that women's issues were swept under the carpet. ${ }^{37}$ The empowerment of Saudi women by the current King cannot be emphasized enough since it is a process to break the chains that had bound women for ages. The king was conscious of extremism's vulnerabilities and the religious fundamentalism that had been supported at the time of King Fahd. King Fahd's rule had occurred in the suspensions of human rights, domestic and regional dangers to the peace and security that every Saudi had longed for. ${ }^{38}$ Therefore, the de facto taking over by Abdullah in 2003 from the ailing King Fahd led to the development of the National Dialogue Center. The dialogue center's main task was to offer a channel for responsible expression towards positively influencing the fight against intolerance, extremism, and zealotry. The center also aimed to create a friendly environment from which both wise positions and enlightened ideas could be developed to cast-off terrorist and terroristic thoughts.

In the infancy stage, Shura was accused of exercising indifference to the Saudis' needs and goals. There was indisputably a central theme of religious principle that seemed to foresee any progressive changes by the council. ${ }^{39}$ Therefore, the Shura Council offers a chance to clean the international perception of the west on the Saudis. As earlier stated, many times, Saudi nationals, including Osama Bin Laden of terrorism and through effective deliberation, the council deliberate on issues that favor the people and discourages extremisms. For instance, the financial theme of vision 2030 offers a chance for every member of Saudi to be financially reliable, eliminating the extremism thoughts. ${ }^{40}$ Addressing the pilgrims one time, King Abdullah warned that extremism begins at home and continues into learning institutions and mosques. Thus ending extremism needed the support of scholars, writers, preachers, intellectuals, and every option, society leader, and the Shura Council. Hence, at the international levels, the Shura Council promotes extremism's end to cleanse the face of Saudi as a place that can be home to anyone irrespective of country of origin. One can invest in Saudi just like any part of the world. In their deliberations, the Shura council handles all matters presented to them by the King, and a solution would be to the benefit of the citizens of Saudi Arabia.

While both international and local expectations continue to run high for Shura Council, to represents the people's wants and aspirations, it is significant to note that in an absolute Monarchy, Shura remains the nearby thing to the Kingdom as

36 Alem, Sarah M. "When We Tell You We Can Do It, Believe Us: An Analysis of the Legislation and Policies Related to the Employment of Women with Disabilities in the Kingdom of Saudi Arabia." (2020).

37 Almutairi, Abdulhamid H. "Resolving insurance disputes in the Kingdom of Saudi Arabia: a critical assessment of the Insurance Dispute Committee." (2020).

${ }^{38}$ GHAZI, Moosa Akefi. "Constitutional Human Rights: Saudi Perspective." Journal of Middle Eastern and Islamic Studies (in Asia) (4, no. 3, 2010)28.

39 Almutairi, Abdulhamid H. "Resolving insurance disputes in the Kingdom of Saudi Arabia: a critical assessment of the Insurance Dispute Committee." (2020).

${ }^{40}$ Moshashai, Daniel, Andrew Leber, and James Savage. "Saudi Arabia plans for its economic future: Vision 2030, the National Transformation Plan and Saudi fiscal reform." British Journal of Middle Eastern Studies (47, no. 3, 2020) 381 
a democratic body. ${ }^{41}$ The Shura council's evolution from an organization that appeared to be rubber-stamping government decision, the current council is a body that questions and seeks answers on pertinent issues that go beyond state polices and forge for important steps to equally people's representation in Saudi according to the king. Every member of the Shura Council understands his or her mandate to the Saudis, who live within and outside the nation. ${ }^{42}$ On international matters, the Shura plays a vital role in advising the king on the steps he should take to promote Saudi Agenda at the global forums. As a country aiming to be an economic hub to Europa, Asian and African continent, the Shura must perform its mandate in line with the shariah and Kings Decrees.

\section{Definition of Shura and the Parliamentary Diplomacy}

Shura defines a political consultation procedure in which the Caliph, ruler, take advice from the elected members of the Majlis Shura, Advisory Council. Islam has three traditional types of schools, School of theology, School of jurisprudence, and the School of Sufi Orders. In both the School of Islamic theology and the School of Jurisprudence, Sunni forms an important Islamic denomination. Shias denomination believe that Ali ibn Abi Talib is the number one successor of Prophet Mohammed. ${ }^{43}$ Sunnis denomination Abu Bakr holds the position as the first successor. Hence Sunni as one of the largest denominations of Islam that are followed by 80 to $90 \%$ of all the Muslims who believe that every decision made by the Muslim societies should be made as per the Shura of the Muslim community. Hence, Shura is believed by the Sunni to be the foundation for applying representative democracy.

On the other hand, the Shia Muslims believe that Islam requires compliance to existing rulers in the event they properly chosen so long as they govern the people as per the Sharia or Islamic Laws. Thus, Islamist consider arguments by Shia Muslim as a traditional approach which dates back to many centuries. Under the Qur'an, Shura is first mentioned in the second Sura of Qur'an 2:233 in an issue of a shared family decision on weaning their kid from mother's milk. The verse inspires the parents of the child to make a mutual decision about the issues. ${ }^{44}$ The forty second Sura is called Shura in the Qur'an. In the $38^{\text {th }}$ verse of the Sura implies that Shura is a commendable lifestyle of a faithful follower. The verse further implies that the people whose issues are under discussion should often be conducted. The Qur'an provides that those who listen to the Lord and often make a regular prayer and those who conduct their issues with mutual consultations among themselves; and those who share out what is part of their nourishment are praised. The $159^{\text {th }}$ verse of the third Sura commands Muhammad to be in consultation with the believers. The verse warns the Muslims who often disobey Mohammad indicating that the loyal Muslims would be consulted.

Shura is, therefore, among the four significant cardinal principles of the Islam perspectives regarding socio-political organization. Human dignity, justice, and equity are other cardinal principles of Islamic perspectives ${ }^{45}$ Shura, in the Islamic world, is different from the democratic principles seen in Western political thoughts. Thus, in the eyes of the Islamic people, Shura is vised in three perspectives. ${ }^{46}$ First, every individual in any society is seen as equal in human and civil privileges. Second, political matters are best decided by popular views. Third, Shura is seen in the principles of human dignity, equality, and justice, which are equally seen as Islam's moral core. ${ }^{47}$ Shura is therefore seen as a principle as opposed to a system of governance. The distinction is significant to note the difference since the Qur'an has advised the successive generations of Muslims to aim at the perfect realization of the Shura Principles.

In modern Muslim nations like Saudi Arabia, Shura plays a significant role in the constitution or governance. Thus a country may decide to rule with a given type of Shura. For example, the bicameral assembly if Pakistan is identified as Majlis-i-Shura even though the Pakistani's constitution adopts different spellings for the Shura. ${ }^{48}$ Egypt also has its Upper House of Parliament called the Shura Council. Additionally, within the clerical and monarchies regimes like

${ }^{41}$ Almutairi, Abdulhamid H. "Resolving insurance disputes in the Kingdom of Saudi Arabia: a critical assessment of the Insurance Dispute Committee." (2020).

42 Alem, Sarah M. "When We Tell You We Can Do It, Believe Us: An Analysis of the Legislation and Policies Related to the Employment of Women with Disabilities in the Kingdom of Saudi Arabia." (2020).

${ }^{43}$ Ibid

${ }^{44}$ Ibid

45 Alem, Sarah M. "When We Tell You We Can Do It, Believe Us: An Analysis of the Legislation and Policies Related to the Employment of Women with Disabilities in the Kingdom of Saudi Arabia." (2020).

${ }^{46}$ Almutairi, Abdulhamid H. "Resolving insurance disputes in the Kingdom of Saudi Arabia: a critical assessment of the Insurance Dispute Committee." (2020).

47 GHAZI, Moosa Akefi. "Constitutional Human Rights: Saudi Perspective." Journal of Middle Eastern and Islamic Studies (in Asia) (4, no. 3, 2010)28.

${ }^{48}$ Ibid 
Saudi Arabia, Shura operates like an advisory or consultative entity. Thus Saudi Arabia gave a shura council name to its parliamentarians, also known as the Consultative Assembly, as earlier mentioned. ${ }^{49}$ Hence under the consultative Assembly the king is elected by the family members. In contrast to the Saudi Arabia Shura council, Oman has all the elected members except the president, an appointee the Sultan. Hence, in Oman, the council can only provide advice to the president, who can further be declined by the Sultan.

\section{The Contribution of Thesis}

From the establishment of the Kingdom of Saudi Arabia to the present, several scholars such as Grigory have contributed to the body of knowledge regarding the system of governance in Saudi Arabia. ${ }^{50}$ The scholars have discussed the formation of the Shura Council and its key mandate to the king and the Saudi people. Other scholars like Karolak and Guta have researched the empowerment of Saudi women, including the inclusion of the Shura Council and other top government positions in the recent past. ${ }^{51}$ Other scholars like John Stuart Mill (1806-1873) and John Rawls (1921-2002) have, in the past, studied and documented their thoughts of economic development as well as social justice to the people of a nation. ${ }^{52}$ Mehrara and Oskoui (2007) too discussed the overreliance on oil by the Kingdom's economy. ${ }^{53}$ Thus all these bodies of knowledge promote growth in different sectors of the economy as well as growth in the legislative systems and general governance of a state.

On the other hand, this current thesis takes a different approach to address the current issues in Saudi Arabia. The main issue currently is the need to meet the goals of the vision 2030. The study seeks to establish if the Kingdom will attain the vision, which is three-pillared. The position of the Kingdom at the center the Arab and Islamic worlds; the willpower to become an international investment powerhouse; the strategic locality with the possibility of becoming a center to link Asia, Europe, and Africa. In attaining the three-pillared goals, the study looks into the Shura Council's role towards the promotion of foreign policies to increase the Kingdom's economic influence in the global markets.

Thus, the thesis adds to the body of knowledge on participatory approaches to legislation that forms part of foreign polices and various ways Saudi Arabia is competent to become an economic hub to Europe, Asia, and Africa. With the overreliance on oil to be reduced, the Kingdom has to increase its production process towards increasing non-oil exports. The body of knowledge developed grids deep into the obstacles in constitutionalism and constitutionalizing normative trends towards attaining legal and political reforms in the Kingdom that can easily yield the fruits of $2030 .{ }^{54}$ Absolute monarchy can be frustrating at the same time, very significant. Hence, the study brings a balance and hope to the citizens never to voice their constitutional needs to the king and the kingdom's machinery. The thesis seeks to identify the gaps in Saudi's executive, legislative and judiciary that threatens the benefits of parliamentary democracy and further denies the country from attaining vision 2030.

\section{Literature Review}

\subsection{Absolute Monarchy}

System of governance differs from one country to another. The most common one in the modern world is Democracy, where the majority of the members of the citizens decide by choosing their leaders through voting. Republic, on the other hand, make decisions by choosing others to make decisions on behalf of other people. Other forms are autocracy and communism, where an individual makes all the rules and where everyone is equal, respectively. In Saudi Arabia, the country is under an absolute monarchy. Verbytska and Tolkachova (2016) defined absolute monarch as the principle of governance where the ultimate power to run a nation or state issues is restored in the hands of a monarch who rules

\footnotetext{
49 Almutairi, Abdulhamid H. "Resolving insurance disputes in the Kingdom of Saudi Arabia: a critical assessment of the Insurance Dispute Committee." (2020).

${ }^{50}$ Grigory, Kosach. "Saudi Arabia: State and Politics." Mirovaya ekonomika i mezhdunarodnye otnosheniya (60, no. 9, 2016) 48.

${ }^{51}$ Karolak, Magdalena, and Hala Guta. "Saudi Women as Decision Makers: Analyzing the Media Portrayal of Female Political Participation in Saudi Arabia." (18, no. 1, 2020)75.

${ }^{52}$ Mill, John Stuart. The basic writings of John Stuart Mill: On liberty, the subjection of women and utilitarianism. (2010).

${ }^{53}$ Mehrara, Mohsen, and Kamran Niki Oskoui. "The sources of macroeconomic fluctuations in oil exporting countries: A comparative study." Economic Modelling (24, no. 3, 2007)365.

${ }^{54}$ Moshashai, Daniel, Andrew Leber, and James Savage. "Saudi Arabia plans for its economic future: Vision 2030, the National Transformation Plan and Saudi fiscal reform." British Journal of Middle Eastern Studies (47, no. 3, 2020) 381
} 
through heavenly right. ${ }^{55}$ Devine right asserts that the position of the king is through a higher power. Under the authority of the monarch, justice, foreign policy, taxes, and administration are performed. MacInnes (2018) remembers one Bishop Jacques-Benigne Bossuet, who lived in the $17^{\text {th }}$ century and was a staunch supporter of the divine right monarchy. According to the Bishop, all administrations were ordained by God, who allowed all mortality to live and operate within a planned society. Since kings and queens were the divine authorities, their power was accorded to them by God, and thus their powers are unconditional. As opposed to a limited monarchy, an absolute monarch does not separate his power with another governing institution like parliament.

In his book, Mansfield (2020) tells the life of one King Louis XIV, who served France between 1643 and 1715 as one of the best examples of absolutism. Louis XIV ascended to the throne at the age of 23, and chief minister Cardinal Richelieu, acted on his behalf leading to the killing of the several nobles who plotted to out-seat the young king. In keeping the divine right to rule, Louis XIV called himself the Sun King, source of light for the subjects. As young as he was, Louis XIV ordered the ministers of state never to sign anything, not even a passport, as he was ready to take up his responsibilities as the king. As a Catholic, Louis XIV, according to Mansfield, closed all the protestant churches and banned them from holding any political meeting. Hence, Louis XIV remained the absolute leader of the French, who led with absolute powers. Therefore, just like the time of King Louis XIV, the Kingdom of Saudi Arabia is under absolute monarchy where the King makes all decisions but with the advice from the Shura Council and Council of ministers.

Countries like Saudi Arabia still embraces Absolute monarchy due to its varied advantages. Bezemek's (2017) opinion that such countries allow quicker decisions to be made. Several times Saudi government has made quick decisions like the inclusion of women to be part of the Shura Council. ${ }^{56}$ If Saudi was a democratic or a republic government, the process of allowing women to be part of the advisors or decision-makers in the council would take edges. Hence, for a quicker decision-making process, a monarch like King Abdullah easily make decisions. The absolute monarchy also makes laws through an easy process. Mansfield (2020) clarifies that under absolute monarchy, there is only one individual who gets to make decisions. In the event, laws are to be made that benefit the citizens, the ruler can command it to be done in due time. Hence, the needs of the people can be addressed within the shortest time possible under an absolute monarchy.

In modern times, not most people would support the absolute monarchy as they feel the decision-making process in absolute monarchy does not capture the people's best interest. Grigory (2016) adds that in the event of an absolute monarchy, once the ruler decides on an issue, the subjects are unable to challenge his decrees. ${ }^{57}$ Just like in other absolute monarchs, the people of Saudi have to make decisions made by the King. While other nations enjoy the democratic process of blocking weak decisions from implementation, the citizens in the absolute monarch must abide by the decision made by the ruler irrespective of the effects of such decisions. However, the Saudi people are staunch followers of the Qur'an which is Holy Book from which they are governed. Quran (3:159-160) supports that it is out of God's compassion that one has been merciful with them, and it is God who put the trust in them (Leaders). Hence as a leader, one should often be in prayers for his subjects since if God forsakes the leaders, then no one would be there to help the leaders. Hence, leaders are God's chosen people and should not act in bad faith or self-interest to harm others. Otherwise, the Almighty will equally punish him as the Qur'an affirms.

\subsection{Judging Legislative Actions}

Scholars have set forth various arguments that aim to judge the legislative actions of a country. Legislative actions of a country like Saudi Arabia may be to the benefits of the society or to their disadvantage. The happiness of society matters when making decisions as a leader. Some leaders would always make decisions in the interest of their family and friend while most of the citizens suffer and remain in abject power. These actions are what John Stuart Mill (1806-1873) discuses in his quest to explain utilitarianism to the political or ruling classes who have the power to make decisions. Mill sees Utilitarianism as a theory that is founded on the principle that actions of decisions are right in the event such actions tend to promote happiness, and the action would be wrong if such actions tend to produce a reverse of happiness. Happiness according to Mill is the pleasure and absence of pain. Mill believes that people set up the government who they believe should protect them from the "vultures" and their "harpies." Unfortunately, many times,

\footnotetext{
55 Verbytska and Tolkachova Features Of the Absolute Monarchy in Foreign Countries: Comparative and Legal Aspect. Constitution, (4, p.11, 2016)

${ }^{56}$ Bezemek. Leviathan's Heir. Enlightenment Philosophy and Hereditary Monarchy. Journal on European History of Law, (8(2), pp.30, 2017).

${ }^{57}$ Grigory, Kosach. "Saudi Arabia: State and Politics." Mirovaya ekonomika i mezhdunarodnye otnosheniya (60, no. 9, 2016) 48.
} 
these governments are seized by the "King of the Harpies." ${ }^{158}$ For instance, on November 4, 2017, a prominent Saudi prince, business people, and government ministers were arrested following a crackdown on corruption. ${ }^{59}$ Corruption, by any means, is against the happiness of the people, and no citizen can ever support a corrupt system. Therefore, Mill believes that a government or ruler's actions should bring happiness to the citizens as opposed to sorrow and suffering. As hinted by Mill, the legislative actions should equally promote justice to the people at all times. As members of the Shura council, justice should be the driving force of their duties and responsibilities to the king and the people of Saudi. For a generation disillusioned with systems, Mill (Ekelund and Tollison, 1987) said that a man with a firm abides by the ultimate value of truth, liberty, and justice coupled with solid principles ad strong believed in their capacity. However, if high spirits and arrogance of youth have been transcended, one will be willing to learn them from experience, practical judgment, and experimental actions. Therefore, social justice is eminent in the fight for a finically stable society.

A legislative approach must equally aim at social justice. Citizens can analyze or judge the legislative actions of parliament leaders based on the principles of social justice. In his theory of justice, John Rawls (1921-2002) suggested that any principle of justice should be founded based on initial hypothetic positions. In the initial position, people often agree on various principles of justice. ${ }^{60}$ Thus according to Rawls, the institution of justice should be guided under the set principles to attain a fair social system. Ekmekci and Arda (2015) support social justice, as discussed by Rawls, and adds the need attainment of the right to health. Ekmekci and Arda defined the right to health as a significant right every individual has per se being human. ${ }^{61}$ The right to health is often considered within the frameworks of the ethical theories and equally supports medical ethics. ${ }^{62}$ Either the Shura Council or the minister should often advise the king accordingly to create a society that embraces social justice. In a just society, recommendations are reached to call for equal basic rights, fairness of opportunity, and endorsing the interests of the least privileged in society.

\subsection{Parliamentary Diplomacy}

According to Fiott (2011), parliamentary diplomacy denotes the means through which two or more parliaments conduct a dialogue to solve an issue under deliberation. ${ }^{63}$ Weiglas and de Boer (2007) also defined parliamentary diplomacy as an array of global actions by parliamentarians in a bid to increase mutual understanding between nations, to help each other towards cultivating effective control of the government as wells as the representing citizens and growth the democratic legitimacy of intergovernmental bodies. Parliamentary diplomacy entails bilateral relations like friendship groups or exchange delegations between parliamentarians or relations between inter-parliamentary organizations and national parliaments. The parliamentarians corporate in a bid to adopt strategies, decisions, or programs which they promote to implement through means like persuasion, institutional pressure, or advocacy.

According to Mudyanadzo and Nkomo, parliamentary diplomacy is a significant instrument in foreign policy. Foreign ministers, ministers, and Prime Ministers play an important role in foreign diplomacy issues as the respective government seeks to create a suitable environment in foreign countries. ${ }^{64}$ Thus their citizens can conduct business without victimization or deportation, the national parliament has a role to play during their cooperation process with other parliaments when solving issues. In many parliaments such as the US, the parliament as the highest legislative institution has the mandate to ratify international treaties, exchange expertise if necessary, and hold meetings with foreign counterparts or committees for a given agenda. In 2019, Saudi Arabia participated in the $14^{\text {th }}$ General Assembly of IPU in Serbia. During the meeting, IPU pledged to support Regional Corporation that could improve the international legal systems and permit the full implementation of its common obligations. The IPU affirmed its commitment to peace and stressing that international laws are the basis for an international order that is founded on solidarity and cooperation. During the meeting, Al-Asheikh reaffirmed the keenness of Saudi Arabia to participate in parliamentary forums that reflect the kingdom's position and its significant roles in attaining security, stability, and peace in both the region and

\footnotetext{
${ }^{58}$ Mill, John Stuart. The basic writings of John Stuart Mill: On liberty, the subjection of women and utilitarianism. (2010).

${ }^{59}$ Kirkpatrick and Hubbard, 2020. Saudi Prince Detains Senior Members Of Royal Family. (2020).

${ }^{60}$ Rawls, J. "A Theory of Justice. Cambridge, MA: Belknap Press of Harvard University Press." (1971).

${ }^{61}$ Ekmekci, Perihan Elif, and Berna Arda. "Enhancing John Rawls's theory of justice to cover health and social determinants of health." Acta bioethica (21, no. 2, 2015) 227.

${ }^{62}$ Ghazi, Moosa Akefi. "Constitutional Human Rights: Saudi Perspective." Journal of Middle Eastern and Islamic Studies (in Asia) 4, no. 3 (2010): 28-46.

${ }^{63}$ Fiott, Daniel. "On the value of parliamentary diplomacy." Madariaga Paper (4, no. 7, 2011)3.

${ }^{64}$ Mudyanadzo, Wenceslaus, and Caleb Asher Nkomo. "Parliamentary Diplomacy as a Critical Component of Zimbabwe's Foreign Policy." International Journal of Politics and Good Governance (7, no. 3, 2016).
} 
international levels.

\subsection{Governance on Economic and Social Outcomes}

Good governance denotes the strong government position both locally and nationally to manage resources like manpower and financial resources towards improving the capital market and investment climate towards keeping bureaucratic systems stable. Good governance also maintains a bureaucratic professionalization toward developing a sound economic power. World Bank, provides that good governance is analyzed through the application capacity of governance values of a nation, providing an outline for both marketplace development and economic growth. Research by Kauffman and Knack verified the link between good governance and market-enhancing governance and recognize a positive correlation between good governance and economic growth. Nevertheless, Mira and Hammadache (2017) provide that good governance policy enables developing nations to attain least economic growth and political improvements in a bid to attain development like developed nations. ${ }^{65}$

Other scholars like Mushtaq Khan have criticized economic development in connection to good governance. In the quest to explain the two different theories of government failures in the developing states, Khan explains in the first thesis (market Enhancing Governance) that state is considered as possessing a sovereign role and being the welfare state. Thus, under economic consideration, the effective functioning of markets is linked to institutions' poor function through appropriate and able application of practices of the state government, which is often called the "good governance." The second thesis advanced by Dany Rodrick and Mushtaq Khan focuses on the state's capacity to put in place social change and follow a voluntary policy of economic expansion. Therefore, these scholars noted that the transition of the developing nations to a capitalist system comparable to the developed nations would not be useful unless efficiently organized in regard to the distribution of political powers in such nations. Hence, such a country will encounter state failure due to a divergence between organizations and economic policy development. Therefore, strong policies must be developed before a nation seeks to promote economic development.

A state or institution of economic development governed by laws and policies can effectively attain economic development due to the order created. Such a system that has policies and laws also ensures social justice is attained as the state works towards empowering every citizen and equal distribution of resources for economic development. Mira and Hammadache outline the indicators of good governance as follows; voice and accountability which indicates the tendencies of the political process, independence of media, civil liberties and political rights; Political instability and violence as an indicator show the perception of a possible destabilization of political regimes through violence or elections; control of corruption as an indicator measures perception of the use of public powers in search for self-interests; quality control, on the other hand, measures the perception that is unfavorable or favorable to a market economy, encompassing anti-liberal interventionists prices like banking systems, price control, and imports and exports; governance effective measured the awareness of the quality of civic administration or civic services. ${ }^{66}$ The rule of law as an indicator measure the awareness of the subjects of rules, which make up the society and the level of agreement with the set rules. The stated indicators are often given a scale of -2.5 to +2.5 . At times the scale is chosen between 0 and 100. Hence, researchers often consider the lowest indicator ad the least favorable. The central aim of developing the indicators is to evaluate good governance of a given country and implement the right policy towards improving the indicators that measured low towards reducing failures by a government to promote good governance that is directory proportional to economic development. Other models developed by the ICRG index include level of education, monetary mass, log of inflation, and coefficient of variation of inflation. Hence, every country, irrespective of the government structure, should aim at good governance that supports economic development.

\section{Research Objections and Aims}

- To evaluate the role of the Shura Council in Saudi Arabia's Transition.

- To identify if Shura Council Become a Catalyst for Change in the Foreign Policy of the Nation.

- Aims to establish political, cultural, and economic forces that hinder legal and political reforms.

${ }^{65}$ Mira, Rachid, and Ahmed Hammadache. "Good governance and economic growth: A contribution to the institutional debate about state failure in Middle East and North Africa." Asian Journal of Middle Eastern and Islamic Studies (11, no. 3, 2017)107.

${ }^{66}$ Mira, Rachid, and Ahmed Hammadache. "Good governance and economic growth: A contribution to the institutional debate about state failure in Middle East and North Africa." Asian Journal of Middle Eastern and Islamic Studies (11, no. 3, 2017) 107 . 


\section{Research Questions}

a) What is the exact role of the parliamentary diplomacy in Saudi Arabia with respect to the formulation of legislation, and what its role in the promotion of foreign policy?

b) Is the parliamentary system meant to advance the participatory approach to legislation? If so, will it advance the cause of foreign policy, particularly that the country is eager to become a hub connecting three continents? If not, what are the political, cultural, historical, social, and economic forces that are making constitutionalism and constitutionalizing normative trends in guiding the legal and political reform of the state?

c) What is the Islamic perspective in this constitutionalism?

d) In the effort to maintain the legitimacy of the governance structures and functions, what democratic reforms can be sought to strengthen the consultative and participatory approaches to governing?

\section{Hypothesis}

H0. Shura council has a clear role to assists Saudi transit to an economic hub.

H1. Shura has no clear roles in assisting Saudi transit to an economic hub.

H0. The current structure of Shura Council permits it to perform its key functions to the people of Saudi Arabia

H1. The current structure of Shura Council does not allow it to perform its key functions to the people of Saudi Arabia

\section{Methodology}

A qualitative method is adopted in the thesis. Qualitative approach provided depth and details and creates openness encouraging the study to expand on the responses. The study depends wholly on secondary data collected online from reputable search engines like Google scholar. However, the general outline of the thesis are as provided later in chapter one. Knowledge production in the field of legal, legislative, constitutional, and political framework at times is accelerating at high speed while the research may remain fragmented and interdisciplinary. Thus, this makes it difficult to keep up with state-of-the-art and be at the top of the research by collecting evidence in a given area of research. This is why literature review becomes a priority method as a more relevant approach than ever. Even though the traditional literature review lacked thoroughness and rigor, the question of the trustworthiness of the literature materials is raised more often than not. Trustworthiness will be affirmed on literature whose analyses have been performed in a precise, exhaustive, consistent manner through disclosing, recording, and systematizing the methods of analysis in which enough information to enable the readers to establish whether the process is credible.

The literature materials selected will encompass as diverse areas as possible to get a comprehensive perspective on this subject, particularly in place of the complex relationship with Islam and the Islamic jurisprudence. This seems quite timely as the Government is earnestly reviewing its pact with the clergy to adopt a modest position in terms of modality of cooperation with other nations and concerning expansion of its international trade in addition to its expanding role in the G20. The review will lead us to formulate a conceptual framework, which is initially very descriptive. As the study involves empirical research, the descriptive framework will be revisited to develop a prescriptive framework.

The research approach will be mainly deductive, moving from theory to hypotheses, observation, and confirmation. In fact, the research will be designed in a way that reflects its interest in understanding the "why" rather than "what". ${ }^{67}$ Although context-specific in their case studies and applicability of recommendations, the worldwide available literature will be brought to frame the boundaries of the present research. This process of framing the boundaries is assumed to be subjective, involving the researcher's understanding of the issues at stake and reflecting the viewpoints of the research subjects.

\section{Research Structure}

The thesis is structured into nine chapters. Chapter One, "General Introduction of The Shura Council and Parliamentary diplomacy." Under the first chapter, the study looks into the general theory of the Shura council, definitions of Shura and the parliamentary diplomacy, and further states the contribution this thesis has in the field of legal, legislative,

${ }^{67}$ Saunders, Mark, Philip Lewis, and Adrian Thornhill. Research methods for business students. Pearson education (2009). 
constitutional, and political frameworks. Further, the first chapter outlines the methodology of the thesis before offering a summary.

Chapter two, "the Concept of the Shura; Roots and Types," embarks on the development of the conceptual framework of the study, Al-Shura history, and the present process before establishing the position of the Islamic deliberation in the society. This chapter also discusses the implications of consultation for good governance.

Chapter Three, "Parliamentary diplomacy," defines parliamentary diplomacy and the extent of its differences or agreements with the official diplomacy. This chapter further provides details Saudi Shura council and the parliamentary diplomacy. Further, it is at the firth chapter that the thesis discusses the domination of the economy, development, epidemics, and treatment of ideologies from the priorities of parliamentary diplomacy. On the other hand, the next section discusses the legal and legislative framework for the Shura Council and the G20. Under this chapter, the Kingdom's presidency of the G20 countries during the Covid-19 pandemic.

Chapter four is one of the most extended chapters in terms of coverage as it discussed the Constitutional laws of Saudi Arabia as well as the role of Shura Council. This chapter discusses the general principles of the constitution, definition of the constitutional laws, and their connections to other sciences like political, financial, and administrative law. The same chapter discusses the source of constitutional laws such as legislation, the Quran and Sunnah. Further, basic laws of governance, the stature of the Shura Council, and allegiance of the commission system are evaluated. Other chapters of the thesis will be as outlined in the subsequent sections of the thesis.

\section{Conclusion}

The Kingdom of Saudi Arabia's leadership under absolute monarchy continues to celebrate its milestones in the nation's governance. On the other hand, the Saudis continue to seek a better leadership structure that embraces democracy, economic development, social justice, and a respecter of human rights and freedom. With every country on the race to achieve social, economic, and political goals as of 2030, Saudi is equally optimistic that the vision 2030 is still a living dream that must be attained. ${ }^{68}$ Even though the absolute monarchy has a characteristic of all decisions made be by the king, which may be an advantage or a disadvantage to the common Saudi's, Saudi Women have registered positive responses for the rulers upon their inclusion in the Shura council. Shura Council is the name of the parliament in Saudi Arabia. The Shura Council members continue discharging their mandate to the king and to the people by holding deliberations that support growth and development. However, allowing the women to be part of the leadership is not enough when the country is geared to be an economic hub for European, Asian, and African continent. Thus to attain an influential position in the worlds' economy, the study looks at a possibility of the Shura Council supporting or being part of the foreign policy development process.

The Shura council must be at the center stage to ensure that exports by the country increase upon favorable foreign policies are established. Indicators of good governance such as quality, justice, and law and order ensure that citizens live a more stable life. Therefore, the transition pursued by Saudi Arabia may only be realized if the king works effectively with the ministers and Shura council members. Further, as an Islamic, the study established that Qur'an is at the center stage of governance since it's the key constitution with which a nation must be governed. Key literature materials to be consulted vary in terms of concept and trustworthiness. Hence, as the thesis insists on literature review as the main methodology, key issues are addressed towards evaluating the preparedness of Saudi's Shura Council towards being a major path to transition. The vast literature that exists is vital towards understanding the entire legislative systems of Saudi Arabia towards achieving vision 2030 that aims at making the citizens financially stable and happy. Hence, the subsequent chapters will provide answers to the key questions asked in the thesis.

\section{References}

Alem, S. M. (2020). When We Tell You We Can Do It, Believe Us: An Analysis of the Legislation and Policies Related to the Employment of Women with Disabilities in the Kingdom of Saudi Arabia. (2020).

AlGhonaim, M., AL-ATTAR, B., Santiago, D. A., Zakaria, H., \& Kamal, M. (2020). SUN-201 CHARACTERISTICS OF DIALYSIS AND RENAL TRANSPLANTATION IN THE KINGDOM OF SAUDI ARABIA. Kidney International Reports, 5(3), S283. https://doi.org/10.1016/j.ekir.2020.02.735

${ }^{68}$ Moshashai, Daniel, Andrew Leber, and James Savage. Saudi Arabia plans for its economic future: Vision 2030, the National Transformation Plan and Saudi fiscal reform. British Journal of Middle Eastern Studies (47, no. 3, 2020) 381 
Aljarallah, S., \& Russell, L. (2018). An exploratory study of software sustainability dimensions and characteristics: end user perspectives in the Kingdom of Saudi Arabia (KSA). Proceedings of the 12th ACM/IEEE International Symposium on Empirical Software Engineering and Measurement, 1-10. https://doi.org/10.1145/3239235.3239240

Almutairi, A. H. (2020). Resolving insurance disputes in the Kingdom of Saudi Arabia: a critical assessment of the Insurance Dispute Committee. PhD diss., University of Sussex, 2020.

Al-Raysuni, A. (2013). Al-Shura: The Qur'anic principle of consultation. International Institute of Islamic Thought (IIIT), 2013.

Bezemek. (2017). Leviathan's Heir. Enlightenment Philosophy and Hereditary Monarchy. Journal on European History of Law, 8(2), 30-36.

Connor, P. (2014) The ability of the European Parliament to enhance the functioning of democracy within the European Union, Durham theses, Durham University. Retrieved from http://etheses.dur.ac.uk/10685/

Cordesman, A. H. (2019). Saudi Arabia: Guarding the desert kingdom. Routledge. https://doi.org/10.4324/9780429497452

Ekelund, R. B., \& Tollison, R. D. (1987). The New Political Economy of JS Mill: the Means. John Stuart Mill: Critical Assessments, 3, 106.

Ekmekci, P. E., \& Berna, A. (2015). Enhancing John Rawls's theory of justice to cover health and social determinants of health. Acta bioethica, 21(2). https://doi.org/10.4067/S1726-569X2015000200009

Fiott, D. (2011). On the value of parliamentary diplomacy. Madariaga Paper, 4(7), 1-6.

GHAZI, M. A. (2010). Constitutional Human Rights: Saudi Perspective. Journal of Middle Eastern and Islamic Studies (in Asia), 4(3), 28-46. https://doi.org/10.1080/19370679.2010.12023160

Grigory, K. (2016). Saudi Arabia: State and Politics. Mirovaya ekonomika i mezhdunarodnye otnosheniya, 60(9), 48-56. https://doi.org/10.20542/0131-2227-2016-60-9-48-56

Held, D., Anthony, McGrew., David, G., \& Jonathan, P. (2000). Global transformations: Politics, Economics and Culture. Politics at the Edge, 14-28. Palgrave Macmillan, London, 2000. https://doi.org/10.1057/9780333981689_2

International Crisis Group. (2004). Can Saudi Arabia Reform Itself? International Crisis Group Middle East Report 28 Cairo/Brussels.

Jalajel, D. S. (2016). Women and Leadership in Islamic Law: A Critical Analysis of Classical Legal Texts. Taylor \& Francis, 2016. https://doi.org/10.4324/9781315649016

Johnson, J. K. (2005). The Role of Parliament in Government. The World Bank Institute. Washington, USA (2005).

Karolak, M., \& Hala, G. (2020). Saudi Women as Decision Makers: Analyzing the Media Portrayal of Female Political Participation in Saudi Arabia. Hawwa, 18(1), 75-95. https://doi.org/10.1163/15692086-12341371

Khan, M. (2008). Governance and development: The perspective of growth-enhancing governance. GRIPS Development Forum/National Graduate Institute for Policy Studies.

Kirkpatrick, D., \& Hubbard, B. (2020). Saudi Prince Detains Senior Members Of Royal Family. [online] Nytimes.com. Retrieved from https://www.nytimes.com/2020/03/06/world/middleeast/saudi-royal-arrest.html

MacInnes, A. I. (2018). Ideas of Monarchical Reform: Fénelon, Jacobitism and the Political Works of the Chevalier Ramsay, by Andrew Mansfield. https://doi.org/10.1093/ehr/cey103

Mansfield, A. (2020). King of the World. The Life of Louis XIV. French History, 34(1), 110-111. https://doi.org/10.1093/fh/craa004

McKinsey Global Institute. (2015). Saudi Arabia Beyond Oil: The Investment and Productivity Transformation.

Mehrara, M., \& Kamran, N. O. (2007). The sources of macroeconomic fluctuations in oil exporting countries: A comparative study. Economic Modelling, 24(3), 365-379. https://doi.org/10.1016/j.econmod.2006.08.005

Mill, J. S. (2010). The basic writings of John Stuart Mill: On liberty, the subjection of women and utilitarianism. Modern Library, 2010. 
Mira, R., \& Ahmed, H. (2017). Good governance and economic growth: A contribution to the institutional debate about state failure in Middle East and North Africa. Asian Journal of Middle Eastern and Islamic Studies, 11(3), 107-120. https://doi.org/10.1080/25765949.2017.12023313

Moshashai, D., Andrew, M. L., \& James, D. S. (2020).Saudi Arabia plans for its economic future: Vision 2030, the National Transformation Plan and Saudi fiscal reform. British Journal of Middle Eastern Studies, (47)3, 381-401. https://doi.org/10.1080/13530194.2018.1500269

Mudyanadzo, We., \& Caleb, A. N. (2016). Parliamentary Diplomacy as a Critical Component of Zimbabwe's Foreign Policy. International Journal of Politics and Good Governance, 7(3).

Rawls, J. (1971). A Theory of Justice. Cambridge, MA: Belknap Press of Harvard University Press.

Saunders, M., Philip, L., \& Adrian, T. (2009). Research methods for business students. Pearson education, 2009.

Shafiq, M. (1984). The role and place of shura in the Islamic polity. Islamic Studies, 23(4), 419-441.

Straub, S. (2000). Empirical Determinants of Good Institutions: Do We Know Anything?. (2000). https://doi.org/10.2139/ssrn.1817222

Sulaimanal, S. J. (1999). The Shura Principle in Islam. Al-Hewar Center website (hewar@alhewar.com). Accessed 22 July 2018

The Saudi Vision 2030. (2016). Retrieved from http://vision2030.gov.sa/en (accessed 23 July 2018)

Verbytska, A. K., \& Tolkachova, I. A. (2016). Features Of the Absolute Monarchy in Foreign Countries: Comparative and Legal Aspect. Constitution, 4, 11.

\section{Copyrights}

Copyright for this article is retained by the author(s), with first publication rights granted to the journal.

This is an open-access article distributed under the terms and conditions of the Creative Commons Attribution license which permits unrestricted use, distribution, and reproduction in any medium, provided the original work is properly cited. 